\title{
Pengembangan Standarisasi Pondok Pesantren
}

\author{
Umar Sidiq \\ Sekolah Tinggi Agama Islam Negeri Ponorogo \\ Email: ashshidik176@gmail.com
}

\begin{abstract}
Pesantren as a forerunner to the original Indonesian educational institution just legally recognized in 2003 through the National Education Law No. 20/ 2003. The pesantren educations that were initially oriented only on deepening religious knowledge have begun to include general subjects. The inclusion of these subjects is expected to expand the horizons of students' thought in which they will also take the national examination held by the government. The informal education outcomes are appreciated to be equivalent to formal education after passing the assessment of equivalency process conducted by agencies appointed by the government or local authorities by reference to national education standards. The pesantren has a special place and position in the national education system. Therefore, the pesantren should always make improvements and increase its education quality.
\end{abstract}

Keywords: standards, pesantren (islamic boarding school), school and the national education law.

\begin{abstract}
Abstrak
Pesantren sebagai cikal bakal lembaga pendidikan yang asli Indonesia baru mendapat pengakuan secara yuridis pada tahun 2003 melalui UU Sisdiknas No. 20 Tahun 2003. Pendidikan pesantren yang pada mulanya hanya berorientasi pada pendalaman ilmu agama semata-mata mulai memasukkan mata pelajaran umum. Masuknya mata pelajaran ini diharapkan untuk memperluas cakrawala berpikir para santri dan biasanya pula para santri mengikuti ujian negara yang diadakan oleh pemerintah. Hasil pendidikan nonformal dapat dihargai setara dengan hasil program pendidikan formal setelah melalui proses penilaian penyetaraan oleh lembaga yang ditunjuk oleh pemerintah atau pemerintah daerah dengan mengacu pada standar nasional pendidikan. Posisi pesantren dalam sistem pendidikan nasional memiliki tempat dan posisi yang istimewa. Karena itu, sudah sepantasnya jika kalangan pesantren terus berupaya melakukan berbagai perbaikan dan meningkatkan kualitas serta mutu pendidikan di pesantren.
\end{abstract}

Kata kunci: standar, pesantren (pondok pesantren Islam), sekolah dan undangundang pendidikan nasional 


\section{A. Pendahuluan}

Pesantren adalah lembaga pendidikan Islam yang sudah berdiri sejak ratusan tahun yang lalu. Di lembaga inilah diajarkan ilmu dan nilai-nilai agama pada santri. Pada tahap awal pendidikan di pesantren tertuju semata-mata mengajarkan ilmu-ilmu agama saja yang diajarkan lewat kitab-kitab klasik atau kitab kuning. Ilmu-ilmu agama yang terdiri dari berbagai cabang diajarkan di pesanten dengan menggunakan metode pembelajaran wetonan, sorogan, hafalan ataupun musyawaroh. Pada tahap awal sistemnya berbentuk nonfomal, tidak dalam bentuk klasikal. Serta lamanya di pesantren tidak ditentukan oleh lamanya tahun belajar, tetapi ditentukan oleh kitab yang dibaca. Dapat juga santri berpindahpindah dari pesantren satu ke pesantren lainnya untuk mendapatkan ilmu yang lebih spesifik dari pesantren yang bersangkutan, dan bisa juga bagi santri yang mempunyai ekonomi lebih melanjutkan pelajaran ke Mekah atau Mesir (Kairo).

Pendidikan pesantren yang pada mulanya hanya berorientasi pada pendalaman ilmu agama semata-mata mulai memasukkan mata pelajaran umum. Masuknya mata pelajaran ini diharapkan untuk memperluas cakrawala berpikir para santri dan biasanya pula para santri mengikuti ujian negara yang diadakan oleh pemerintah. Selain itu di dunia pesantren juga diperkenalkan berbagai bentuk keterampilan agar santri dapat mengisi waktu luang dengan ilmu pengetahuan dan keterampilan, sehingga mampu untuk bekerja dan mengamalkan ilmunya, yang diharapkan para alumni pesantren bisa bermanfaat ketika terjun di masyarakat.

\section{B. Landasan Yuridis Kedudukan Pendidikan Pondok Pesantren Dalam Undang-Undang}

Secara yuridis, politik pendidikan di Indonesia dituangkan dalam Undang-undang Sistem Pendidikan. Sampai kini telah diterbitkan 3 (tiga) Undang-undang Sistem Pendidikan Nasional, yaitu Undang-undang Pokok Pendidikan dan Pengajaran No. 4 Tahun 1950 jo Undang-undang No. 12 Tahun 1954 yang diterbitkan pada masa Orde Lama, UU Sisdiknas No. 2 Tahun 1989 pada masa Orde Baru, dan UU Sisdiknas No. 20 Tahun 2003 pada masa reformasi. Pesantren sebagai cikal bakal lembaga pendidikan 
yang asli Indonesia baru mendapat pengakuan secara yuridis pada tahun 2003 melalui UU Sisdiknas tersebut. ${ }^{1}$

Merujuk pada Undang-undang Nomor 20 tahun 2003 tentang Sistem Pendidikan Nasional, posisi dan keberadaan pesantren sebenarnya memiliki tempat yang istimewa. Namun, kenyataan ini belum disadari oleh mayoritas masyarakat muslim. Karena kelahiran Undang-undang ini masih amat belia dan belum sebanding dengan usia perkembangan pesantren di Indonesia. Keistimewaan pesantren dalam sistem pendidikan nasional dapat kita lihat dari ketentuan dan penjelasan pasal-pasal dalam Undangundang Sisdiknas sebagai berikut:

1. Dalam Pasal 3 UU RI Nomor 20 tahun 2003 Sisdiknas dijelaskan bahwa pendidikan nasional berfungsi mengembangkan kemampuan dan membentuk watak serta peradaban bangsa yang bermartabat dalam rangka mencerdaskan kehidupan bangsa, bertujuan untuk berkembangnya potensi peserta didik agar menjadi manusia yang beriman dan bertakwa kepada Tuhan Yang Maha Esa, berakhlaq mulia, sehat, berilmu, cakap, kreatif, mandiri, dan menjadi warga negara yang demokratis serta bertanggung jawab. ${ }^{2}$ Ketentuan ini tentu saja sudah berlaku dan diimplementasikan di pesantren. Pesantren sudah sejak lama menjadi lembaga yang membentuk watak dan peradaban bangsa serta mencerdaskan kehidupan bangsa yang berbasis pada keimanan dan ketakwaan kepada Allah SWT. serta akhlaq mulia.

2. Ketentuan dalam Bab III tentang Prinsip Penyelenggaraan Pendidikan, pada Pasal 4 dijelaskan bahwa: a) Pendidikan diselenggarakan secara demokratis dan berkeadilan serta tidak diskriminatif dengan menjunjung tinggi hak asasi manusia, nilai keagamaan, nilai kultural, dan kemajemukan bangsa; b) Pendidikan diselenggarakan sebagai satu kesatuan yang sistemik dengan sistem terbuka dan multimakna; c) Pendidikan diselenggarakan sebagai suatu proses pembudayaan dan pemberdayaan peserta didik yang berlangsung sepanjang hayat; d) Pendidikan diselenggarakan dengan memberi keteladanan, membangun kemauan, dan mengembangkan kreati-

1 Ali Anwar, Pembaruan Pendidikan di Pesantren Lirboyo Kediri (Yogyakarta: Pustaka Pelajar, 2011), hlm. 35.

2 Made Pidarta, Manajemen Pendidikan Indonesia (Jakarta: Rineka Cipta, 2004), hlm. 6. 
vitas peserta didik dalam proses pembelajaran; e) Pendidikan diselenggarakan dengan mengembangkan budaya membaca, menulis, dan berhitung bagi segenap warga masyarakat; f). Pendidikan diselenggarakan dengan memberdayakan semua komponen masyarakat melalui peran serta dalam penyelenggaraan dan pengendalian mutu layanan pendidikan. ${ }^{3}$ Semua prinsip penyelenggaraan pendidikan tersebut sampai saat ini masih berlaku dan dijalankan di pesantren.

3. Ketentuan mengenai Hak dan Kewajiban Masyarakat pada Pasal 8 menegaskan bahwa masyarakat berhak berperan serta dalam perencanaan, pelaksanaan, pengawasan, dan evaluasi program pendidikan. Sedangkan dalam Pasal 9 dijelaskan bahwa masyarakat berkewajiban memberikan dukungan sumber daya dalam penyelenggaraan pendidikan. ${ }^{4}$ Ketentuan ini berarti menjamin eksistensi dan keberadaan pesantren sebagai lembaga pendidikan yang diselenggarakan masyarakat dan diakomodir dalam sistem pendidikan nasional. Hal ini dipertegas lagi oleh Pasal 15 tentang jenis pendidikan yang menyatakan bahwa jenis pendidikan mencakup pendidikan umum, kejuruan, akademik, profesi, vokasi, keagamaan, dan khusus. ${ }^{5}$ Pesantren adalah salah satu jenis pendidikan yang concern di bidang keagamaan. Secara khusus, ketentuan tentang pendidikan keagamaan ini dijelaskan dalam Pasal 30 Undang-Undang Sisdiknas yang menegaskan: a) Pendidikan keagamaan diselenggarakan oleh Pemerintah dan/atau kelompok masyarakat dari pemeluk agama, sesuai dengan peraturan perundang-undangan; b) Pendidikan keagamaan berfungsi mempersiapkan peserta didik menjadi anggota masyarakat yang memahami dan mengamalkan nilai-nilai ajaran agamanya dan/atau menjadi ahli ilmu agama; c) Pendidikan keagamaan dapat diselenggarakan pada jalur pendidikan formal, nonformal, dan informal; d) Pendidikan keagamaan berbentuk pendidikan diniyah, pesantren, dan bentuk lain yang sejenis. ${ }^{6}$

${ }^{3}$ Surayin, Undang-Undang Republik Indonesia Nomor 20 Tahun 2003 tentang Sistem Pendidikan Nasional (Bandung: Yrama Widya, 2004), hlm. 26-27.

${ }^{4}$ Surayin, Undang-Undang ..., hlm. 31.

${ }^{5}$ Surayin, Undang-Undang ..., hlm. 37.

${ }^{6}$ Surayin, Undang-Undang ..., hlm. 58-59. 
Lebih jauh lagi, saat ini pesantren tidak hanya berfungsi sebagai sarana pendidikan keagamaan semata.

4. Ketentuan mengenai lembaga pendidikan nonformal ini termuat dalam Pasal 26 yang menegaskan: a) Pendidikan nonformal diselenggarakan bagi warga masyarakat yang memerlukan layanan pendidikan yang berfungsi sebagai pengganti, penambah, dan/atau pelengkap pendidikan formal dalam rangka mendukung pendidikan sepanjang hayat; b) Pendidikan nonformal berfungsi mengembangkan potensi peserta didik dengan penekanan pada penguasaan pengetahuan dan keterampilan fungsional serta pengembangan sikap dan kepribadian profesional; c) Pendidikan nonformal meliputi pendidikan kecakapan hidup, pendidikan anak usia dini, pendidikan kepemudaan, pendidikan pemberdayaan perempuan, pendidikan keaksaraan, pendidikan keterampilan dan pelatihan kerja, pendidikan kesetaraan, serta pendidikan lain yang ditujukan untuk mengembangkan kemampuan peserta didik; d) Satuan pendidikan nonformal terdiri atas lembaga kursus, lembaga pelatihan, kelompok belajar, pusat kegiatan belajar masyarakat, dan majelis taklim, serta satuan pendidikan yang sejenis; e) Kursus dan pelatihan diselenggarakan bagi masyarakat yang memerlukan bekal pengetahuan, keterampilan, kecakapan hidup, dan sikap untuk mengembangkan diri, mengembangkan profesi, bekerja, usaha mandiri, dan/atau melanjutkan pendidikan ke jenjang yang lebih tinggi; f) Hasil pendidikan nonformal dapat dihargai setara dengan hasil program pendidikan formal setelah melalui proses penilaian penyetaraan oleh lembaga yang ditunjuk oleh Pemerintah atau pemerintah daerah dengan mengacu pada standar nasional pendidikan. ${ }^{7}$

5. Keberadaan pesantren sebagai bagian dari peran serta masyarakat dalam pendidikan juga mendapat penguatan dari UU Sisdiknas Pasal 54 menjelaskan: a) Peran serta masyarakat dalam pendidikan meliputi peran serta perseorangan, kelompok, keluarga, organisasi profesi, pengusaha, dan organisasi kemasyarakatan dalam penyelenggaraan dan pengendalian mutu pelayanan pendidikan; b) Masyarakat dapat berperan

\footnotetext{
${ }^{7}$ Surayin, Undang-Undang ..., hlm. 51-52.
} 
serta sebagai sumber, pelaksana, dan pengguna hasil pendidikan. ${ }^{8}$

6. Pesantren yang merupakan pendidikan berbasis masyarakat diakui keberadaannya dan dijamin pendanaannya oleh pemerintah maupun pemerintah daerah. Pasal 55 menegaskan: a) Masyarakat berhak menyelenggarakan pendidikan berbasis masyarakat pada pendidikan formal dan nonformal sesuai dengan kekhasan agama, lingkungan sosial, dan budaya untuk kepentingan masyarakat; b) Penyelenggara pendidikan berbasis masyarakat mengembangkan dan melaksanakan kurikulum dan evaluasi pendidikan, serta manajemen dan pendanaannya sesuai dengan standar nasional pendidikan; c) Dana penyelenggaraan pendidikan berbasis masyarakat dapat bersumber dari penyelenggara, masyarakat, pemerintah, pemerintah daerah dan/atau sumber lain yang tidak bertentangan dengan peraturan perundang-undangan yang berlaku; d) Lembaga pendidikan berbasis masyarakat dapat memperoleh bantuan teknis.

Demikianlah, ternyata posisi pesantren dalam sistem pendidikan nasional memiliki tempat dan posisi yang istimewa. Karena itu, sudah sepantasnya jika kalangan pesantren terus berupaya melakukan berbagai perbaikan dan meningkatkan kualitas serta mutu pendidikan di pesantren. Pemerintah telah menetapkan Renstra Pendidikan tahun 2005-2009 dengan tiga sasaran pembangunan pendidikan nasional yang akan dicapai, yaitu: 1) meningkatnya perluasan dan pemerataan pendidikan; 2) meningkatnya mutu dan relevansi pendidikan; dan 3) meningkatnya tata kepemerintahan (governance), akuntabilitas, dan pencitraan publik. Maka, dunia pesantren harus bisa merespon dan berpartisipasi aktif dalam mencapai kebijakan di bidang pendidikan tersebut. Pesantren tidak perlu merasa minder, kerdil, kolot atau terbelakang. Karena pesantren juga telah ikut mencerdaskan bangsa.

\section{Manajemen Mutu Berbasis Pondok Pesantren}

Ketika menginjak abad ke-20, yang sering disebut sebagai jaman modernisme dan nasionalisme, peranan pesantren mulai mengalami pergeseran secara signifikan. Sebagian pengamat

\footnotetext{
${ }^{8}$ Surayin, Undang-Undang ..., hlm. 95.
} 
mengatakan bahwa semakin mundurnya peran pesantren di masyarakat disebabkan adanya dan begitu besarnya faktor politik Hindia Belanda. ${ }^{9}$

Sehingga, fungsi dan peran pesantren menjadi bergeser dari sebelumnya. Tapi, penjelasan di atas kiranya cukup untuk menyatakan bahwa pra abad ke-20 atau sebelum datangnya modernisme dan nasionalisme, pesantren merupakan lembaga pendidikan yang tak tergantikan oleh lembaga pendidikan manapun. Dan, hal itu sampai sekarang masih tetap dipertahankan. Paling menarik di sini adalah bahwa pendidikan pesantren di Indonesia pada saat itu sama sekali belum terstandarisasi secara kurikulum dan tidak terorganisir sebagai satu jaringan pesantren Indonesia yang sistemik. Ini berarti bahwa setiap pesantren mempunyai kemandirian sendiri untuk menerapkan kurikulum dan mata pelajaran yang sesuai dengan aliran agama Islam yang mereka ikuti. Sehingga, ada pesantren yang menerapkan kurikulum Departemen Pendidikan Nasional dengan menerapkan juga kurikulum agama. Kemudian, ada pesantren yang hanya ingin memfokuskan pada kurikulum ilmu agama Islam saja. Yang berarti bahwa tingkat keanekaragaman model pesantren di Indonesia tidak terbatasi. Setelah kemerdekaan negara Indonesia, terutama sejak transisi ke Orde Baru dan ketika pertumbuhan ekonomi betul-betul naik tajam, pendidikan pesantren menjadi semakin terstruktur dan kurikulum pesantren menjadi lebih tetap. Misalnya, selain kurikulum agama, sekarang ini kebanyakan pesantren juga menawarkan mata pelajaran umum. Bahkan, banyak pesantren sekarang melaksanakan kurikulum Depdiknas dengan menggunakan sebuah rasio yang ditetapkannya, yaitu 70 persen mata pelajaran umum dan 30 persen mata pelajaran agama. Sekolah-sekolah Islam yang melaksanakan kurikulum Depdiknas ini kebanyakan di Madrasah. ${ }^{10}$

Seiring dengan keinginan dan niatan yang luhur dalam membina dan mengembangkan masyarakat, dengan kemandiriannya, pesantren secara terus-menerus melakukan upaya pengembangan dan penguatan diri. Walaupun terlihat berjalan secara lamban, kemandirian yang didukung keyakinan yang kuat, ternyata pesan-

9 Aqib Suminto, Pesantren dan Madrasah (Yogyakarta: Pustaka Pelajar, 2002), hlm. 3.

${ }^{10}$ Sulthon Masyhud dkk., Manajemen Pondok Pesantren (Jakarta: Diva Pustaka, 2003), hlm. 73. 
tren mampu mengembangkan kelembagaan dan eksistensi dirinya secara berkelanjutan. Mengutip pendapat Said Agil Siraj (2007), ada tiga hal yang belum dikuatkan dalam pesantren:

a. Tamaddun yaitu memajukan pesantren. Banyak pesantren yang dikelola secara sederhana. Manajemen dan administrasinya masih bersifat kekeluargaan dan semuanya ditangani oleh kyainya. Dalam hal ini, pesantren perlu berbenah diri.

b. Tsaqafah yaitu bagaimana memberikan pencerahan kepada umat Islam agar kreatif-produktif, dengan tidak melupakan orisinalitas ajaran Islam. Salah satu contoh para santri masih setia dengan tradisi kepesantrenannya. Tetapi, mereka juga harus akrab dengan komputer dan berbagai ilmu pengetahuan serta sains modern lainnya.

c. Hadarah yaitu membangun budaya. Dalam hal ini, bagaimana budaya kita dapat diwarnai oleh jiwa dan tradisi Islam. Di sini, pesantren diharapkan mampu mengembangkan dan mempengaruhi tradisi yang bersemangat islami di tengah hembusan dan pengaruh dahsyat globalisasi yang berupaya menyeragamkan budaya melalui produk-produk teknologi. ${ }^{11}$

Namun demikian, pesantren akan tetap eksis sebagai lembaga pendidikan Islam yang mempunyai visi mencetak manusiamanusia unggul. ${ }^{12}$ Prinsip pesantren adalah al muhafazah 'ala al qadim aș-salih, wal akhżu bil jadid as-aslah, yaitu tetap memegang tradisi yang positif, dan mengimbangi dengan mengambil hal-hal baru yang positif. Persoalan-persoalan yang berpautan dengan civic values akan bisa dibenahi melalui prinsip-prinsip yang dipegang pesantren selama ini dan tentunya dengan perombakan yang efektif, berdaya guna, serta mampu memberikan kesejajaran sebagai umat manusia (al-musawwah bainannas). Sebagai sebuah lembaga yang bergerak dalam bidang pendidikan dan sosial keagamaan, pengembangan pesantren harus terus didorong. Karena pengembangan pesantren tidak terlepas dari adanya kendala yang harus dihadapinya. Apalagi belakangan ini, dunia secara dinamis telah menunjukkan perkembangan dan perubahan secara cepat, yang tentunya, baik secara langsung maupun tidak langsung dapat berpengaruh terhadap dunia pesantren. Terdapat beberapa

${ }^{11}$ Abdurrahman Mas'ud, Sejarah dan Budaya Pesantren, dalam Ismail Sm (ed),: Dinamika Pesantren dan Madrasah (Jakarta: LP3ES, 1985), hlm. 18.

12 Mujamil Qomar, Pesantren dari Transformasi Metodologi menuju Demokratisasi Institusi (Jakarta: Erlangga, 2002), hlm. 5. 
hal yang tengah dihadapi pesantren dalam melakukan pengembangannya, yaitu:

1. Image pesantren sebagai sebuah lembaga pendidikan yang tradisional, tidak modern, informal, dan bahkan teropinikan sebagai lembaga yang melahirkan terorisme, telah mempengaruhi pola pikir masyarakat untuk meninggalkan dunia pesantren. Hal tersebut merupakan sebuah tantangan yang harus dijawab sesegera mungkin oleh dunia pesantren dewasa ini.

2. Sarana dan prasarana penunjang yang terlihat masih kurang memadai. Bukan saja dari segi infrastruktur bangunan yang harus segera dibenahi, melainkan terdapat pula yang masih kekurangan ruangan pondok (asrama) sebagai tempat menetapnya santri. Selama ini, kehidupan pondok pesantren yang penuh kesederhanaan dan kebersahajaannya tampak masih memerlukan tingkat penyadaran dalam melaksanakan pola hidup yang bersih dan sehat yang didorong oleh penataan dan penyediaan sarana dan prasarana yang layak dan memadai.

3. Sumber daya manusia. Sekalipun sumber daya manusia dalam bidang keagamaan tidak dapat diragukan lagi, tetapi dalam rangka meningkatkan eksistensi dan peranan pondok pesantren dalam bidang kehidupan sosial masyarakat, diperlukan perhatian yang serius. Penyediaan dan peningkatan sumber daya manusia dalam bidang manajemen kelembagaan, serta bidang-bidang yang berkaitan dengan kehidupan sosial masyarakat, mesti menjadi pertimbangan pesantren.

4. Aksesibilitas dan networking. Merupakan salah satu kebutuhan untuk pengembangan pesantren. Penguasaan akses dan networking dunia pesantren masih terlihat lemah, terutama sekali pesantren-pesantren yang berada di daerah pelosok dan kecil. Ketimpangan antar pesantren besar dan pesantren kecil begitu terlihat dengan jelas.

5. Manajemen kelembagaan. Manajemen merupakan unsur penting dalam pengelolaan pesantren. Pada saat ini masih terlihat bahwa pondok pesantren dikelola secara tradisional apalagi dalam penguasaan informasi dan teknologi yang masih belum optimal. Hal tersebut dapat dilihat dalam proses pendokumentasian (data base) santri dan alumni pondok pesantren yang masih kurang terstruktur.

6. Kemandirian ekonomi kelembagaan. Kebutuhan keuangan selalu menjadi kendala dalam melakukan aktivitas pesantren, 
baik yang berkaitan dengan kebutuhan pengembangan pesantren maupun dalam proses aktivitas keseharian pesantren. Tidak sedikit proses pembangunan pesantren berjalan dalam waktu lama karena menunggu sumbangan atau donasi dari pihak luar, bahkan harus melakukan penggalangan dana di pinggir jalan.

7. Kurikulum yang berorientasi life skills santri dan masyarakat. Pesantren masih berkonsentrasi pada peningkatan wawasan dan pengalaman keagamaan santri dan masyarakat. Apabila melihat tantangan kedepan yang semakin berat, peningkatan kapasitas santri dan masyarakat tidak cukup.

\section{Integrasi Antara Pendidikan Sekolah dan Pesantren}

1. Format Pesantren Ideal

Berangkat dari kenyataan, jelas pesantren di masa sekarang dituntut berbenah, menata diri dalam menghadapi persaingan bisnis pendidikan seperti yang telah dilakukan oleh Muhammadiyah dan lainnya. Tapi perubahan dan pembenahan yang dimaksud hanya sebatas manajemen dan bukan coraknya apalagi berganti baju dari saläfiyah ke mu'așir(modern), karena hal itu hanya akan menghancurkan nilai-nilai positif pesantren seperti yang terjadi sekarang ini, lulusannya ora iso ngaji. Maka, idealnya pesantren ke depan harus bisa mengimbangi tuntutan zaman dengan mempertahankan tradisi dan nilai-nilai kesalafannya. Pertahankan pendidikan formal pesantren khususnya kitab kuning dari Ibtidaiyah sampai Aliyah sebagai KBM wajib santri dan mengimbanginya dengan pengajian tambahan, kegiatan extra seperti kursus komputer, Bahasa Inggris, skill lainnya dan program paket $\mathrm{A}, \mathrm{B}$ dan $\mathrm{C}$ untuk mendapatkan ijazah formalnya. Atau dengan menjalin kerjasama dengan sekolah lain untuk mengikuti persamaan. Jika hal ini terjadi, akan lahirlah ustadz-ustadz, ulama dan fuqoha yang mumpuni.

Sekarang ini, ada dua fenomena menarik dalam dunia pendidikan di Indonesia yakni munculnya sekolah-sekolah terpadu (mulai tingkat dasar hingga menengah); dan penyelenggaraan sekolah bermutu yang sering disebut dengan boarding school. Nama lain dari istilah boarding school adalah sekolah berasrama. Para murid mengikuti pendidikan 
reguler dari pagi hingga siang di sekolah, kemudian dilanjutkan dengan pendidikan agama atau pendidikan nilainilai khusus di malam hari. Selama 24 jam anak didik berada di bawah pengawasan para guru pembimbing. Di lingkungan sekolah ini mereka dipacu untuk menguasai ilmu dan teknologi secara intensif. Selama di lingkungan asrama mereka ditempa untuk menerapkan ajaran agama atau nilainilai khusus tadi, tak lupa mengekspresikan rasa seni dan ketrampilan hidup di hari libur. Hari-hari mereka adalah harihari berinteraksi dengan teman sebaya dan para guru. Rutinitas kegiatan dari pagi hari hingga malam sampai ketemu pagi lagi, mereka menghadapi makhluk hidup yang sama, orang yang sama, lingkungan yang sama, dinamika dan romantika yang seperti itu pula. Dalam khazanah pendidikan kita, sekolah berasrama adalah model pendidikan yang cukup tua. Secara tradisional jejaknya dapat kita selami dalam dinamika kehidupan pesantren, pendidikan gereja, bahkan di bangsal-bangsal tentara. Pendidikan berasrama telah banyak melahirkan tokoh besar dan mengukir sejarah kehidupan umat manusia. Kehadiran boarding school adalah suatu keniscayaan jaman kini. Keberadaannya adalah suatu konsekuensi logis dari perubahan lingkungan sosial dan keadaan ekonomi serta cara pandang religiusitas masyarakat.

a. Lingkungan sosial kita kini telah banyak berubah terutama di kota-kota besar. Sebagian besar penduduk tidak lagi tinggal dalam suasana masyarakat yang homogen, kebiasaan lama bertempat tinggal dengan keluarga besar satu klan atau marga telah lama bergeser ke arah masyarakat yang heterogen, majemuk, dan plural. Hal ini berimbas pada pola perilaku masyarakat yang berbeda karena berada dalam pengaruh nilai-nilai yang berbeda pula. Oleh karena itu sebagian besar masyarakat yang terdidik dengan baik menganggap bahwa lingkungan sosial seperti itu sudah tidak lagi kondusif bagi pertumbuhan dan perkembangan intelektual dan moralitas anak.

b. Keadaan ekonomi masyarakat yang semakin membaik mendorong pemenuhan kebutuhan di atas kebutuhan dasar seperti kesehatan dan pendidikan. Bagi kalangan menengah-atas yang baru muncul akibat tingkat pendidikan mereka yang cukup tinggi sehingga mendapatkan posisi-posisi yang baik dalam lapangan pekerjaan 
berimplikasi pada tingginya penghasilan mereka. Hal ini mendorong niat dan tekad untuk memberikan pendidikan yang terbaik bagi anak-anak melebihi pendidikan yang telah diterima orang tuanya.

c. Cara pandang religiusitas. Masyarakat telah, sedang, dan akan terus berubah. Kecenderungan terbaru masyarakat perkotaan sedang bergerak ke arah yang semakin religius. Indikatornya adalah semakin diminati dan semaraknya kajian dan berbagai kegiatan keagamaan. Modernitas membawa implikasi negatif dengan adanya ketidakseimbangan antara kebutuhan rohani dan jasmani. Untukitu masyarakat tidak ingin hal yang sama akan menimpa anak-anak mereka. Intinya, ada keinginan untuk melahirkan generasi yang lebih agamis atau memiliki nilainilai hidup yang baik mendorong orang tua mencarikan sistem pendidikan alternatif. Dari ketiga faktor di atas, sistem pendidikan boarding school seolah menemukan pasarnya.

Dari segi sosial, sistem boarding school mengisolasi anak didik dari lingkungan sosial yang heterogen yang cenderung buruk. Di lingkungan sekolah dan asrama dikonstruksi suatu lingkungan sosial yang relatif homogen yakni teman sebaya dan para guru pembimbing. Homogen dalam tujuan yakni menuntut ilmu sebagai sarana mengejar cita-cita. Dari segi ekonomi, boarding school memberikan layanan yang paripurna sehingga menuntut biaya yang cukup tinggi. Oleh karena itu anak didik akan benar-benar terlayani dengan baik melalui berbagai layanan dan fasilitas. Terakhir dari segi semangat religiusitas, boarding school menjanjikan pendidikan yang seimbang antara kebutuhan jasmani dan ruhani, intelektual dan spiritual. Diharapkan akan lahir peserta didik yang tangguh secara keduniaan dengan ilmu dan teknologi, serta siap secara iman dan amal soleh. Nampaknya, konsep boarding school menjadi alternatif pilihan sebagai model pengembangan pesantren yang akan datang.

Beberapa pesantren yang sistem pendidikannya terintegrasi antara lain: Pesantren Suryalaya Tasikmalaya, Pesantren alMasturiyah Sukabumi dan Pondok Pesantren Pertanian Darul Falah di Kabupaten Bogor. Semua santri/pelajar dan mahasiswa yang belajar di sekolah/madrasah dan perguruan 
tinggi tersebut, menetap di kampus pondok pesantren, belajar sepanjang hari dan malam sesuai dengan program-program pondok pesantren. Semua pelajar dan mahasiswa sekaligus menjadi santri pada pondok pesantren tersebut. ${ }^{13}$

Pemerintah diharapkan semakin serius dalam mendukung dan mengembangkan konsep pendidikan seperti ini. Pesantren menjadi lembaga pendidikan yang maju dan bersaing dalam mengembangkan ilmu pengetahuan dan keterampilan yang berbasis pada nilai-nilai spiritual yang handal.

2. Perlunya Kebijakan Pemerintah untuk Mendukung Pesantren

Sudah tidak diragukan lagi bahwa pesantren memiliki kontribusi nyata dalam pembangunan pendidikan. Apalagi dilihat secara historis, pesantren memiliki pengalaman yang luar biasa dalam membina dan mengembangkan masyarakat. Bahkan, pesantren mampu meningkatkan perannya secara mandiri dengan menggali potensi yang dimiliki masyarakat di sekelilingnya. ${ }^{14}$ Pembangunan manusia, tidak hanya menjadi tanggung jawab pemerintah atau masyarakat semata-mata, tetapi menjadi tanggung jawab semua komponen, termasuk dunia pesantren. Pesantren yang telah memiliki nilai historis dalam membina dan mengembangkan masyarakat, kualitasnya harus terus didorong dan dikembangkan. Proses pembangunan manusia yang dilakukan pesantren tidak bisa dipisahkan dari proses pembangunan manusia yang tengah diupayakan pemerintah.

Proses pengembangan dunia pesantren yang selain menjadi tanggung jawab internal pesantren, juga harus didukung oleh perhatian yang serius dari proses pembangunan pemerintah. Meningkatkan dan mengembangkan peran serta pesantren dalam proses pembangunan merupakan langkah strategis dalam membangun masyarakat, daerah, bangsa, dan negara. Terlebih, dalam kondisi yang tengah mengalami krisis (degradasi) moral. Pesantren sebagai lembaga pendidikan yang membentuk dan mengembangkan nilai-nilai moral, harus menjadi pelopor sekaligus inspirator pembangkit moral bangsa. Sehingga, pembangunan tidak menjadi hampa

13 A. Tafsir dkk., Cakrawala Pemikiran Pendidikan Islam (Bandung: Mimbar Pustaka, 2004), hlm. 195.

${ }^{14}$ Marwan Saridjo, Bunga Rampai Pendidikan Agama Islam (Jakarta: Amissco, 1996), hlm. 13. 
melainkan lebih bernilai dan bermakna. Pesantren pada umumnya bersifat mandiri, tidak tergantung kepada pemerintah atau kekuasaan yang ada. Karena sifat mandirinya itu, pesantren bisa memegang teguh kemurniannya sebagai lembaga pendidikan Islam. Karena itu, pesantren tidak mudah disusupi oleh ajaran-ajaran yang tidak sesuai dengan ajaran Islam.

\section{E. Dasar Pengembangan Standarisasi Pondok Pesantren}

Sebagaimana dijelaskan, pada era reformasi ini pendidikan keagamaan mendapat tempat dengan telah diundangkannya UU No. 20 Tahun 2003 yang telah disahkan Presiden pada tanggal 8 Juli 2003 setelah melalui perdebatan panjang di masyarakat dan Dewan Perwakilan Rakyat. Dalam Undang-undang ini, diakui kehadiran pendidikan keagamaan sebagai salah satu jenis pendidikan disamping pendidikan umum, kejuruan, akademik, profesi, vokasi dan ketrampilan khusus.

Tiga tahun sebelumnya, tepatnya pada masa pemerintahan Presiden Abdurahman Wahid, semestinya pesantren telah mendapatkan beberapa kemudahan. Melalui SKB dua menteri No. 1/U/KB/2000 dan Nomor MA/86/2000 para santri di pesantren salafiyah yang berusia 7-15 tahun yang mengikuti pendidikan Diniyah Awaliyah (tingkat dasar) dan Diniyah Wustho (tingkat lanjutan pertama), yang tidak sedang menempuh pendidikan pada SD/MI dan SLTP/MTs atau bukan pula tamatan keduanya, dapat diakui memiliki kemampuan yang setara dan kesempatan yang sama untuk melanjutkan belajar ke jenjang pendidikan yang lebih tinggi, bila pesantren tersebut menambah beberapa pelajaran umum minimal 3 mata pelajaran, yakni Bahasa Indonesia, Matematika dan IPA. STTB atau Ijazah yang dikeluarkan oleh pesantren penyelenggara program ini diakui oleh pemerintah setara dengan STTB SD/MI atau SLTP/MTs dan dapat dipergunakan untuk melanjutkan ke jenjang pendidikan yang lebih tinggi dengan syarat-syarat yang akan diatur oleh departemen terkait.

Dalam rangka melaksanakan ketentuan pasal 12 ayat (4), pasal 30 ayat (5), pasal 37 ayat (3) UU Sisdiknas No. 20 Tahun 2003 diundangkanlah Peraturan Pemerintah Republik Indonesia Nomor 55 Tahun 2007 tentang pendidikan agama dan pendidikan keagamaan. Beberapa pasal dari Peraturan Pemerintah ini pada 
dasarnya menguatkan berbagai keputusan yang telah ditetapkan Departemen Agama dan Departemen Pendidikan Nasional sebelumnya. Ayat (1) Pasal 11 Bab III, menjelaskan bahwa peserta didik pada pendidikan keagamaan jenjang pendidikan dasar dan menengah yang terakreditasi berhak pindah ke tingkat yang setara di Sekolah Dasar, Madrasah Ibtidaiyah, Sekolah Menengah Pertama, Madrasah Tsanawiyah, Sekolah Menengah Atas, Madrasah Aliyah, Sekolah Menengah Kejuruan, Madrasah Aliyah Kejuruan, atau bentuk lain yang sederajat setelah memenuhi persyaratan. Ayat (2) dari pasal 11 menjelaskan bahwa hasil pendidikan keagamaan nonformal dan/atau informal dapat dihargai sederajat dengan hasil pendidikan formal keagamaan/umum/kejuruan setelah lulus ujian yang diselenggarakan oleh satuan pendidikan yang terakreditasi yang ditunjuk oleh Pemerintah dan/atau pemerintah daerah. Sedangkan ayat (3) nya adalah peserta didik pendidikan keagamaan formal, nonformal, dan informal yang memperoleh ijazah sederajat pendidikan formal umum/kejuruan dapat melanjutkan ke jenjang berikutnya pada pendidikan keagamaan atau jenis pendidikan lainnya.

Berdasarkan data diatas diketahui bahwa pesantren dan madrasah diniyah sebagai sumber pendidikan dan pencerdasan masyarakat Indonesia, yang sudah berurat akar sejak sebelum kemerdekaan ternyata baru mendapatkan pengakuan secara yuridis pada era reformasi ini. ${ }^{15}$ Posisi pesantren, khususnya pesantren salaf yang semata menjalankan kurikulum ilmu keislaman yang belum diakui pemerintah, antara lain karena pesantren salaf lazimnya tidak menerapkan ketentuan pemberian ijazah kepada para santri yang telah menyelesaikan pendidikan. Sampai akhir tahun 1990-an masih ada lulusan pesantren, yang karena belum mendapatkan pengakuan pemerintah tidak dapat melanjutkan pendidikannya ke perguruan tinggi negeri keagamaan seperti IAIN dan STAIN. Kendala lain dapat berupa tidak diakuinya pendidikan mereka ketika mencari lapangan pekerjaan. Dengan adanya kendala-kendala tersebut, banyak dari lembaga pendidikan Islam pola pesantren ini mengubah pendidikannya ke dalam bentuk madrasah dan menerapkan kurikulum yang ditetapkan oleh peme-

15 Ali Anwar, Pembaruan Pendidikan di Pesantren Lirboyo Kediri (Yogyakarta: Pustaka Pelajar, 2011), hlm. 49-53. 
rintah, sehingga lulusannya mendapatkan pengakuan baik dari pemerintah maupun dari sektor lain. ${ }^{16}$

Respon masyarakat dalam memanfaatkan momentum bagi proses pendidikan tampaknya cukup memuaskan. Atas kesadarannya sendiri, mereka berpartisipasi dalam menjamin kelangsungan proses pendidikan dengan cara memasukkan putra-putrinya ke sekolah. Sikap yang positif ini ternyata merupakan tantangan paling berat bagi kelangsungan pesantren. Khususnya bagi pesantren kecil, keadaan tersebut mengakibatkan musibah paling dahsyat sepanjang kehidupannya. Dhofier melaporkan bahwa kebanyakan pesantren kecil mati pada tahun 1950-an. Pesantrenpesantren besar dapat bertahan, tetapi setelah memasukkan lembaga-lembaga pendidikan umum di dalamnya. Kini semakin banyak pesantren yang menyelenggarakan SMP, SMA. Musibah yang hampir sama menimpa pesantren kembali pada tahun 1970an ketika sekularisasi gencar memasuki seluruh aspek kehidupan manusia di Indonesia.

Pelacakan terhadap latar belakang timbulnya lembaga-lembaga pendidikan umum di pesantren seperti SD, SMP dan SMA akan menemukan paling tidak dua jawaban: pertama, sebagai upaya pesantren dalam melakukan adaptasi dengan perkembangan pendidikan nasional, atau oleh Mastuhu dikatakan karena dampak global dari pembangunan nasional serta kemajuan ilmu pengetahuan dan teknologi. Dan kedua adalah karena kepentingan "menyelamatkan nyawa" pesantren dari kematian selama-lamanya. Kebutuhan adaptasi sebenarnya telah dirintis sejak mendirikan madrasah, yang memperlancar proses pembaharuan kelembagaan. Sedang upaya penyelamatan kehidupan pesantren merupakan tindakan yang strategis dan spontan. Kedua faktor ini saling mempengaruhi berdirinya lembaga-lembaga pendidikan umum sebagai pengembangan (pemantapan pembaharuan) institusi pesantren.

Lembaga-lembaga pendidikan umum seperti SD, SMP dan SMA tersebut terus berkembang, bahkan semakin mendapat dukungan dari masyarakat santri yang memiliki keterikatan moral dengan pesantren. Mereka ingin agar putra-putrinya belajar ngaji di pesantren sekaligus dapat mengikuti pendidikan di SD, SMP dan SMA di dalamnya, lantaran cara demikian lebih memberikan

${ }^{16}$ Nurhayati Djamas, Dinamika Pendidikan Islam di indonesia Pascakemerdekaan (Jakarta: Rajawali Pers, 2009), hlm. 189-190. 
jaminan keutuhan pribadi santri. Sebab disamping pengetahuan dan pengalaman ajaran agama tertanam dengan baik, santri juga dapat mengembangkan potensi intelektualnya melalui penerapan sistem pembelajaran yang modern. ${ }^{17}$

Akhirnya, tanpa banyak pertimbangan kebanyakan pesantren mengikuti sistem yang dikembangkan pemerintah secara keseluruhan. Maka beberapa pesantren cenderung mendirikan perguruan tinggi dengan meniru sistem perguruan tinggi nasional secara totalitas. Para pengamat melaporkan bahwa banyak pesantren besar seperti Tebuireng, Tambakberas, Rejoso, Gontor, dan Cipasung yang mendirikan perguruan tinggi dengan membuka fakultas-fakultas agama Islam seperti Ushuluddin, Syari'ah, Tarbiyah, Dakwah dan Adab, serta fakultas umum seperti Hukum, Ekonomi, Sosial Politik dan sebagainya. Di Jawa Barat juga banyak yang membuka fakultas, misalnya pesantren As-Syafi'iyyah dan Cipasung. Di luar Jawa, pesantren yang telah mendirikan perguruan tinggi adalah Pesantren Diayatul Islamiyyah di Seriguna Tanjung Lubuk Ogan Komering Ilir, Sumatra Selatan.

\section{F. Penutup}

Hasil pendidikan nonformal dapat dihargai setara dengan hasil program pendidikan formal setelah melalui proses penilaian penyetaraan oleh lembaga yang ditunjuk oleh Pemerintah atau pemerintah daerah dengan mengacu pada standar nasional pendidikan. Para santri di pesantren salafiyah yang berusia 7-15 tahun yang mengikuti pendidikan Diniyah Awaliyah (tingkat dasar) dan Diniyah Wustho (tingkat lanjutan pertama), yang tidak sedang menempuh pendidikan pada SD/MI dan SLTP/MTs atau bukan pula tamatan keduanya, dapat diakui memiliki kemampuan yang setara dan kesempatan yang sama untuk melanjutkan belajar ke jenjang pendidikan yang lebih tinggi, bila pesantren tersebut menambah beberapa pelajaran umum minimal 3 mata pelajaran, yakni Bahasa Indonesia, Matematika dan IPA. STTB atau Ijazah yang dikeluarkan oleh pesantren penyelenggara program ini diakui oleh pemerintah setara dengan STTB SD/MI atau SLTP/MTs dan dapat dipergunakan untuk melanjutkan ke jenjang pendidikan yang lebih

\footnotetext{
${ }^{17}$ Mujamil Qomar, Pesantren dari ..., hlm. 97-98.
} 
tinggi dengan syarat-syarat yang akan diatur oleh departemen terkait.

Hasil pendidikan keagamaan nonformal dan/atau informal dapat dihargai sederajat dengan hasil pendidikan formal keagamaan/umum/kejuruan setelah lulus ujian yang diselenggarakan oleh satuan pendidikan yang terakreditasi yang ditunjuk oleh Pemerintah dan/atau pemerintah daerah. Peserta didik pendidikan keagamaan formal, nonformal, dan informal yang memperoleh ijazah sederajat pendidikan formal umum/kejuruan dapat melanjutkan ke jenjang berikutnya pada pendidikan keagamaan atau jenis pendidikan lainnya.

\section{Kepustakaan}

Anwar, Ali. 2011. Pembaruan Pendidikan di Pesantren Lirboyo Kediri. Yogyakarta: Pustaka Pelajar.

Djamas, Nurhayati. 2009. Dinamika Pendidikan Islam di Indonesia Pascakemerdekaan. Jakarta: Rajawali Pers.

Mas'ud, Abdurrahman. 1985. Sejarah dan Budaya Pesantren, dalam Ismail Sm (ed) : Dinamika Pesantren dan Madrasah. Jakarta: LP3ES.

Masyhud, Sulthon dkk. 2003. Manajemen Pondok Pesantren. Jakarta: Diva Pustaka.

Pidarta, Made. 2004. Manajemen Pendidikan Indonesia. Jakarta: Rineka Cipta.

Qomar, Mujamil. 2002. Pesantren dari Transformasi Metodologi menuju Demokratisasi Institusi. Jakarta: Erlangga.

Saridjo, Marwan. 1996. Bunga Rampai Pendidikan Agama Islam. Jakarta: Amissco.

Suminto, Aqib. 2002. Pesantren dan Madrasah. Yogyakarta: Pustaka Pelajar.

Surayin. 2004. Undang-Undang Republik Indonesia Nomor 20 Tahun 2003 tentang Sistem Pendidikan Nasional. Bandung: Yrama Widya.

Tafsir, A. dkk. 2004 Cakrawala Pemikiran Pendidikan Islam. Bandung: Mimbar Pustaka. 
